\title{
European grants to face ethics scrutiny
}

[PARIS] European life scientists seeking research grants from the European Union (EU)'s next five-year Framework programme (FP5), due to start at the end of next year, may soon face an additional hurdle - the requirement that research proposals receive a stamp of 'ethical approval' from the European Commission.

The recommendation that the ethical implications of all such proposals be systematically evaluated is likely to form part of an 'opinion' on the commission's proposals for FP5 due to be released next week by the commission's Group of Advisers on the Ethics of Biotechnology.

The opinion is expected to justify such a move on the grounds that research is not 'neutral', and that its potential social and moral impact should be considered from the outset. It is expected to state formally that scientific freedom should not be given priority over risks to safety or human rights.

This argument drew a broad consensus at a meeting in Brussels last week of all the national ethics bodies of the EU member states, convened by the commission to provide input into the advisory group's opinion. "It is obvious that there is a tension between the freedom of science and the social responsibility of scientists, and that scientific liberty is not absolute," says group member Anne McLaren, a prominent reproductive biologist and former foreign secretary of Britain's Royal Society.

Although it is unclear how the suggested evaluation will operate in practice, the commission's proposals for FP5 already state for the first time that research supported should "comply with fundamental ethical principles". It explicitly bans funding for research on human germline gene therapy and human cloning, and states that animals used in experiments must where possible be replaced by in vitro or other alternative techniques.

One conclusion from last week's meeting was that the commission should not make ethical judgements on issues such as human embryo research where no consensus exists among member states. But it was also agreed that all proposals should be screened to comply with certain principles, such as the need to weigh up the benefits of animal research against the suffering caused.

The opinion is also likely to state that even if a research practice is forbidden in one country, that will not be sufficient to forbid it at European level. More controversially, the group is likely to recommend that research proposals potentially giving rise to broad ethical concerns, such as the search for genes related to homosexuality, should receive special in-depth evaluation. At the same time, the group recognizes that there are limits to the responsibility of researchers.
One recommendation that may prove embarrassing for the commission is the group's conclusion that fundamental research itself has an 'ethical value'. The opinion is likely to state that the EU has a moral responsibility to shift its funding away from applied research to fundamental research, on the grounds that the latter is being neglected in member states because of the emphasis on wealth creation. "The EU should be supporting research that might not be funded otherwise," says one group member.

More broadly, the commission's decision to bring together all national ethics committees underlines the growing political importance of bioethics in the EU. Jacques Santer, the commission president, who himself attended the meeting, said that a "balance" has to be struck between the economic prospects of new technology and the "human and social dimension".

Indeed, Santer said he intended to extend the group's remit to include all new technologies. The group itself is likely to recommend the incorporation of all the national ethics committees within a European ethics network under its umbrella. It is also likely to recommend closer links between the group and the European Parliament, whose members have often criticized it as a 'puppet' of the commission.

According to Noelle Lenoir, chairwoman of the group, ethical evaluation at the European level is likely to be based more on the Anglo-Saxon 'pragmatic' approach of weighing up the pros and cons of particular cases, rather than the French approach of drafting legislation based on abstract principles such as the need to respect 'human dignity'.

Although the EU's founding treaties give it no formal competence in bioethics, the existence of directives on issues such as genetically modified organisms and gene patents makes litigation in such areas inevitable, according to Jean-Pierre Puissochet, a judge at the European Court of Justice.

The increased emphasis on bioethics within the EU is considered as inevitable and welcome by many observers. Some are concerned, however, that it will place unnecessary burdens on scientists and raises the risk of subjective assessment of research proposals on their political correctness. Projects "could be censored on grounds of public acceptability" warns one commission official, adding that after the BSE crisis, "everyone [at the commission] is trying to cover their backside".

DeclanButler

\section{[PARIS] The European}

Commission is to tighten a directive first issued in 1991 covering the deliberate release of genetically modified organisms into the environment. Revisions include the compulsory monitoring of products such as transgenic maize for harmful effects for seven years after their approval.

Under the proposed measures, full details of which are to be announced this week, the commission's scientific advisory committees will have to be consulted about all applications for the release of genetically modified organisms. Another provision allows the commission, for the first time, to refer dossiers to its Group of Advisers on the Ethics of Biotechnology (see above).

Ritt Bjerregaard, the environment commissioner, says that the new measures demonstrate that the

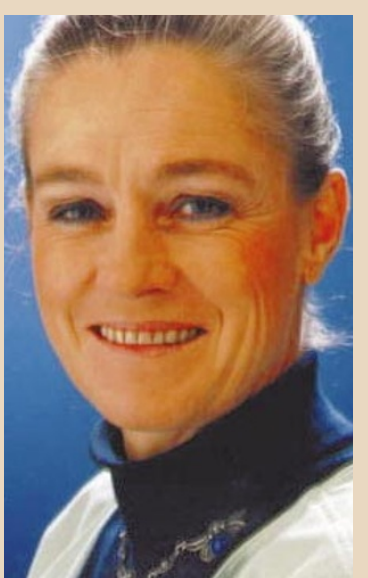

Bjerregaard: aware of public concern and debate.

commission "pays careful attention to public concern and public debate". The commission has already agreed that all products containing genetically modified organisms should be labelled, and is due to release details of labelling procedures this month.

The proposals, which need the approval of the ministers of the 15 member states of the European Union, are aimed at breaking a deadlock over genetically modified crops. Although last year the union approved modified maize produced by Switzerland's Novartis, imports of the maize have been banned by Austria, Luxembourg and Italy on the grounds that they may pose health risks - a position challenged by the commission and France.

In a related development, the French government last week lifted a ban on the growing of genetically modified maize. But it said that further studies were needed on the production and sale of other crops, such as rapeseed and sugar beet.

Louis Le Pensec, the agriculture minister, said that the ban introduced by the previous government "was not coherent to authorize imports of genetically modified maize while prohibiting cultivation". 